\title{
Integrating ICT in Re-Branding Nigerian Youths for Constructive Empowerment and Mental Reengineering
}

\author{
U.F. Eze \\ B.Sc. M.Sc. Ph.D., MNCS, MCPNG.N Okeudo, AnyiamKizito; Etus Chukwuemeka ‘ \\ Federal University of Technology, Owerri
}

\begin{abstract}
Today, there is need to reposition our youths mental reasoning and economically empower them in order to certify the demands of the modern world. Rebranding Nigerian is one of the veritable tools to achieve this objective. Unless rebranding directs the power and energy of Nigerian youths towards academic and productive goals, the country keeps on experiencing social vices,moral and academic degradation. Gladly enough, Nigeria has joined the rest of the world in deploying ICT to ensure easy and quick enlightenment and empowerment of its populace. Obviously, ICT has grossly engaged most of the Nigerian teenagers and youths in performing educational, social, economical, governmental or religious activities in different dimensions nowadays. Therefore, this paper highlights the impact and areas where ICT has yielded positive change in rebranding Nigerian youths in achieving better mental capacity building.
\end{abstract}

Key Word: ICT, Rebranding, Nigerian youths empowerment, mental reengineering.

\subsection{DEFINITION OF ICT}

\section{Introduction}

ICT is an acronym that stands for Information and Communication Technology. It is a composite term, which embodies three important concepts: information, communication and technology. Womboh (2008) submits that to understand the term ICT, one must understand all the three concepts. He then defines information as scientifically processed data which aids decision making. But for Babu, Singh and Sachdeva (1997), information means data that has been put into a meaningful and useful context and communicated to a potential user who uses it to make decisions. Womboh (2008) also defines communication as the transfer or exchange of information from person to person or from one place to another, while he describes technology as the use of scientific knowledge to create tools for enabling human beings to subdue environmental hazards and obstructions to comfort. The computer, telephone, cell phone, GSM handsets, television, radio, etc are given as examples of products of communication technology.

Coming to the definition of ICT, deWatteville and Gilbert (2000) in Womboh (2008) have defined it in the following terms: The acquisition, analysis, manipulation, storage and distribution of information as well as the design and provision of equipment and software for these purposes. ICT is also defined as the various technologies that enhance the creation, storage, processing, communication and dissemination of information. ICTs also refer to the different infrastructures used in these processes, their applications and the numerous services these infrastructures render. The elements of ICTs include communication media (e.g radio, television,) information machine (e.g computers) and telecommunications technologies and equipment (e.g satellites, fiber optic cables, phones, and facsimile machines).

Telecommunications infrastructures in particular have turn out to be the driving forces of ICTs because they have the ability to link all various ICT elements together irrespective of locations and to provide a converging platform for them.ICT also refer to the different infrastructures used in these processes, their applications and the numerousservices these infrastructures render.

(cbdd.wsu.edu/kewlcontent/cdoutput/TR501/page9.htm).

The elements of ICT include communication media (e.g radio, television,) information machine (e.g computers) and telecommunications technologies and equipment (e.g satellites, fiber optic cables, phones, and facsimile machines). Telecommunications infrastructures in particular have turn out to be the driving forces of ICT because they have the ability to link all various ICT elements together irrespective of locations and to providea converging platform for them all (cbdd.wsu.edu/kewlcontent/cdoutput/TR501/page9.htm). The scope of ICT covers any product that will store, retrieve, manipulate, transmit or receive information electronically in a digital form. For example, personal computers, digital television, email, robots. So ICT is concerned with the storage, retrieval, manipulation, transmission or receipt of digital data. Importantly, it is also concerned with the way these differentuses can work with each other (http://tutor2u.net/business/ict/intro_what_is_ict.htm). 


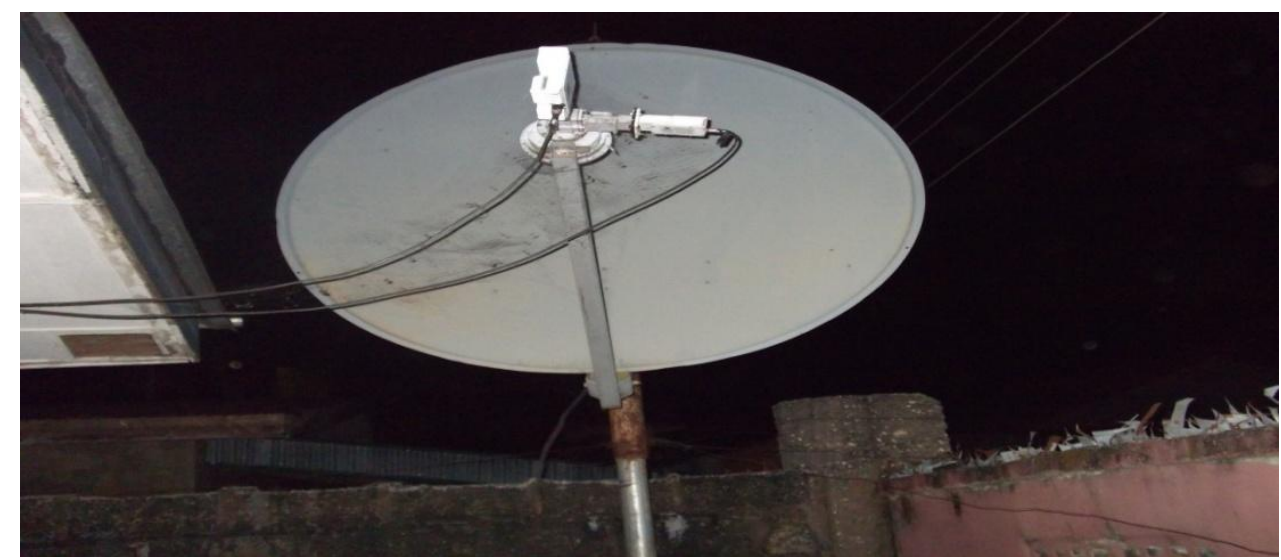

FIG 1-TELECOMMUNICATIONS INFRASTRUCTURES SUPPORTING ICT

\subsection{THE STATE OF ICT IN NIGERIA}

Ogunsola and Aboyade (2005) observe that Nigeria had a late start in the use of computers, but the growth in their use has been quite remarkable. The computer installations are widely distributed in universities, government departments and agencies, banks, commercial establishments, and industries. The private sector is also not left out in this information technological revolution. Nigerian university campuses too are now full of Information Communication technology facilities enabling lecturers and students to do their researches and other academic works using various IT devices. They also note with happiness that both the Federal Government of Nigeria and other international funding agencies are interested in the general development of ICT in higher education in Nigeria. The Federal Ministry of Education, for instance, has embarked on the establishment of the National Virtual (Digital) Library Project. Funding agencies like Carnegie Corporation of New York are also interested in the Nigerian ICT developmental programme. Mobile cellular services made their first appearance on the Nigerian market in 1993 with a "national" service operated by NITEL and a smaller Lagos service operated by Mobile Telecommunications Services (MTS). The two firms, with a joint subscriber base of 12500 , provided voice services over an analogue E-TACS network, as well as basic value-added services such as voicemail and paging, from three switches in Lagos, Enugu, and Abuja. However, in 1995, MTS closed its operations due to failure to pay interconnection charges to NITEL. M-Tel subsequently emerged as NITEL's mobile service provider. The GSM licensing process was cancelled early in 2000 and the process of auctioning four mobile cellular licenses was reopened in December of that year, after soliciting credible bidders. The winners who emerged out of this process and settled the agreed license fees included Econet Wireless Nigeria, Mobile Telephone Networks (MTN) and Communications Nigeria. The new GSM licenses were awarded for a period of five years (renewable) and all operators can operate in the $900 \mathrm{MHz}$ and $1800 \mathrm{MHz}$ spectrum bands. Whereas they do provide for a potential upgrading of future networks to GPRS (general packet radio switching), they do not encompass third generation (3G) networks, which will probably be auctioned off sometime in the future. Nigeria's digital mobile network has grown significantly since the three companies, awarded the Global System for Mobile Communications (GSM) license in January 2001, began operating in August 2001. According to the Nigerian Communications Commission (NCC) the GSM network achieved 350,000 connections within six months of their launch (Telecommunication in Nigeria-Overview http://www.mbendi.com/indy/cotl/tlcm/af/ng/p0005.htm)

By September 7, 2010, nine years since the introduction of GSM in Nigeria, the country has witnessed an unprecedented massive development of telecom infrastructure across the country by the operators. Indeed, the rate of investment in the telecom sector since 1999 is regarded only second to the oil industry. With over 45 million subscriber bases, Nigeria's telecommunication industry is regarded as the fastest growing in the world. This has opened up huge business opportunities in the telecom industry. The GSM has also revolutionized our business environment as people can transact their businesses from the comfort of their homes through the use of GSM facilities. At the same time social relationships have been enhanced. GSM has also empowered the people economically through creation of mass employment. Today, so many unemployed people are earning their living by making phone calls, selling recharge cards and GSM accessories. GSM has equally become a major source of revenue for the government.

The NCC has continued to introduce necessary measures to enhance the quality of service delivery and steady growth of the industry. The measures include the introduction of unified licensing, which made it possible for fixed wireless operators to offer GSM service. Equally significant is the granting of $3 \mathrm{G}$ licenses to some operators. The 3G, as it is popularly called, is the most advanced technology on GSM, which enables the operators to offer both data, voice video conference services (Udutchay, 2008). Awe (2009) says for Nigeria to truly celebrate the October 2009 independence, ICT must be called to the party as it is an engine for sustainable 
development in health, education, agriculture, poverty reduction, wealth creation, employment, security, youth empowerment and other key sectors. Awe's assessment of the state of the ICT in the country includes the following, among others:

a) Telecommunication availability has improved and Nigeria is one of the world's fastest growing mobile markets. But the cold, hard facts are that communications quality is low and ICT penetration is still insufficient considering Nigeria's size and population.

b) It's important to note that important variations in the nature of access determine telecommunication impact, for instance, broadband density is particularly low as there is a great gulf between broadband and voice telephony penetration. Nigeria must move beyond voice telephony.

c) Furthermore, cost is a barrier. Lack of awareness and access excludes many from the digital environment. In a country where poverty still walks the streets, ICT remains a stranger. Computing and telecommunication resources areunaffordable to the majority.

d) Software is at the heart of the global knowledge economy. Any nation that values its sovereignty must take software serious. Software opportunities in Nigeria are not being fully exploited to unleash the potentials of the Nigerian people and the Nigerian nation. Local developers however facechallenges of ignorance and patronage. Existing software promotion policies have not made much impact. Bureaucratic sloganeering will not get us anywhere.

e) Information security is an area of concern. Cybercrime, hacking, phishing, ATM fraud and general identity theft are on the increase. Security of information assets is critical to building confidence in today's networked world. Having secure information environments helps in attracting more investment in ICT.

\subsection{REBRANDING}

Branding has traditionally been associated with products and services, with countries, places and cities. Global companies and corporations and their marketing communications agencies have continued to create and use branding as distinguishing and strategic competitive factor in the market place, and also in the fierce market drive for consumers. Most of the definitions of branding focused directly and more on explaining what brand means. Nilson (2000) writes that "A brand is really just a symbol with tremendous potential, and that this symbol can be expressed in many different ways." On the other hand, rebranding is defined as the process of changing the old methods of doing things and strategically creating a better attitude towards doing the same thing for competitive advantage and or for better image portrayal.Nigerians are a very confident people who believe in themselves. We see success in our lives in the form of individuals overcoming innumerable odds. That is why when Prof. Dora Akunyili initiated and manned the re-branding project, she thought it wise to deploy the various components of ICT as tools to help achieve vision of rebranding Nigeria. Thanks to ICT, today many Nigerian youths can boast of having being re-branded and are making waves all around the world. However, Nigerians do not have much faith in their government. That is understandable because over time the government has not fulfilled its duties to the people, many of whom remain poor or lack basic infrastructure and necessities. Since its launch as, the "Nigeria, Good People, Great Nation" this project hit a few bumps along the way and faced criticisms, constructive arguments and stuff like that. Although many of Nigerian Curiosity's readers disagree, I personally believe that it is an effort worthy of support because Nigeria's image definitely needs an upgrade.

\section{Role of Ict in Re-Branding Nigerian Youths}

The role of ICT in re-branding Nigeria is a peculiar one because ICT is a veritable tool for fast and effective mass communication. The impact of ICT in the world today is far reaching and pervades all boundaries and cultural differences. It's the platform for globalization. As a result, ICT can help Nigeria achieve a global re-branded image. The various components of ICT being the media, internet, broadcast and cable TV and even telephone services can be deployed as tools for the awareness, campaign and implementation of the re-branding project.

Over the years, when it comes to international media and internet, Nigeria has been associated with bad images. Doing business or any form of online activity has always posed a challenge. Nigerians have become synonymous with cyber crime. For effective re-branding all components of ICT and at all levels must be deployed in enlightening, training, and encouraging people towards re-branding.As much as through the use of ICT many Nigerians have been branded badly, through the use of ICT many Nigerians can redeem their image.

\subsection{THE IMPACT OF ICT ON EDUCATION IN REBRANDING NIGERIAN YOUTHS}

Almost every sector in Nigeria is being revolutionized by the advent of Information and Communication Technology (ICT) policy, as noted by Rowland (1996) and cited in Hafkin (2002). The education sector has experienced tremendous changes and improvements with the latest application of ICT. The system and methods of acquisition of knowledge has dramatically changed by ICT, access to educational 
resources such as books, newspapers, admission information, researched information etc., have been made easy by Information and Communication Technology. These new developments in a way have rebranded Nigeria youths.

The influence of information technology on social practices has mainly been to the effect of making information about them more accessible. The most relevant question though is whether the developments in information technologies have influenced the continuity of social attitudes, customs or institutions. Social attitudes have changed with the effect that Youths of Nigeria now expect the various elements of Nigeria to be better informed than previously; as the saying goes - if one is not informed, one is deformed! They also expect to be able to access more information about a specific product, service or organization so that they can make informed decisions with regard to their interactions with that entity. The word institutions can incorporate a wide variety of organizations such as governments, commercial businesses, news and media organizations and educational organizations.

Developments such as the Internet and satellite television have created new medium and audiences through which and to which these organizations can disseminate their information. The relative cheapness of being able to publish information on the Internet means that virtually anyone can publish information accessible anywhere in the world. As information technology has developed over the past years, educational establishments have been influenced in various ways. The most obvious example has been the introduction of information technology related courses. These courses are introduced to try to satisfy the demand that society has for qualified youths to develop these information technologies. The developments that have occurred in information technology have also had other influences on educational establishments. Educational organizations have a goal to distribute information from a source to the student. The processes by which educational establishments distribute information have become increasingly diverse and the effectiveness of the process has also improved.The distribution of information is not the only concern of educational establishments. For example one of the aims of Universities is to create information. This creation is done by research. Information and communication technologies have enabled researchers to access a wider source of information than previously available through such technologies as the Internet. The Internet and other related technologies such as electronic mail also enable collaborative projects to be undertaken between geographically distant youths. The youths are only key players in the information society if they have been well educated, which gives them with the informational abilities to survive in a new and globalized economy. Information is a key factor to any development process. The Internet as an information and communication medium has come to play a major role in the distribution of information. Information and communication Technologies (ICTs) have changed the way information is stored, disseminated and processed.(Cloke\& Sharif, 2001).

\subsubsection{ICT CONTRIBUTIONS ON QUALITATIVE EDUCATION IN NIGERIA}

Improving the quality of education and training is a critical issue, particularly at a time of educational expansion. ICT has enhanced the quality of education sector in Nigeria in several ways such as increasing learner motivation and engagement, facilitating the acquisition of basic skills, enhancing teacher training (Wadi\& Sonia, 2002). An effective ICT classroom to achieve an enhanced education in Nigeria is shown below

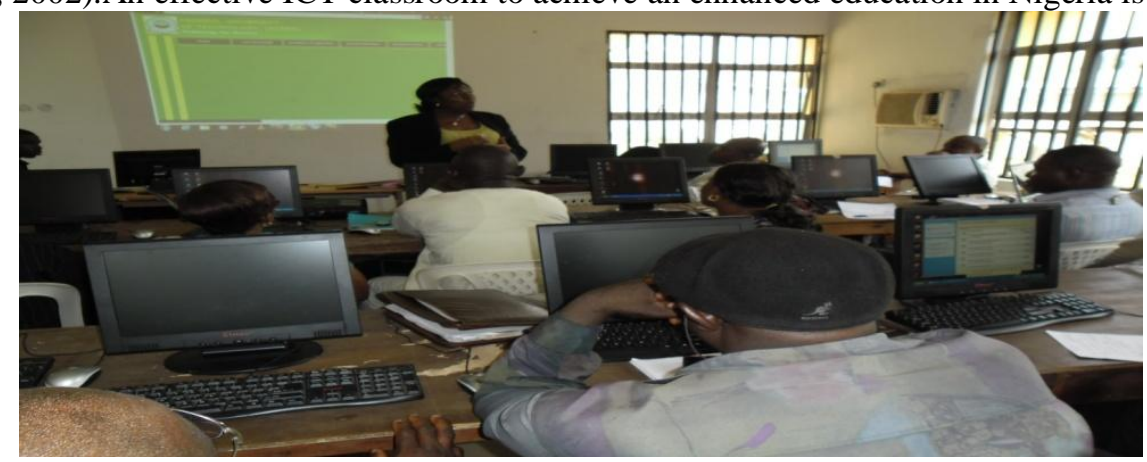

FIG. 2 -ICT APPLICATION IN A CLASSROOM

ICTs are also transformational tools which, when appropriately used can promote the shift to a learner-centered environment. The following are some of the ways in which ICT have enhanced quality education:

$>$ Motivating Learning Materials: ICTs such as videos, television and multimedia computer software that combine text, sound, and colorful, moving images can be used to provide challenging and authentic content that will engage the student in the learning process and tele-collaboration. This methods shows that the average young person in Nigeria would pay up to $80 \%$ attention to visual educational material than the normal class room work. This improvement has contributed in the rebranding of the Nigerian youths by the creation of learning appetite which was depreciating in the society. Interactive radio likewise makes use of 
sound effects, songs, dramatizations, comic skits, and other performance conventions to compel the students to listen and become involved in the lessons being delivered. More so than any other type of ICT, networked computers with Internet connectivity can increase learner motivation as it combines the media richness and interactivity of other ICTs with the opportunity to connect with real people and to participate in real world events.

> Facilitating the acquisition of basic skills: The transmission of basic skills and concepts that are the foundation of higher order thinking skills and creativity can be facilitated by ICTs through drill and practice. Educational television programs such as "Who Want to be a Millionaire"; Nigeria's biggest thought provoking program, enlightens the youths because of the questions that are required to be answered before the cash price is awarded. Questions are drawn from all works of life ranging from religious, cultural, educational to contemporary issues, thereby facilitating the acquisition of basic skills amongst populace.

> Enhancing teacher training: ICTs have also been used to improve access to and the quality of teacher training. For example, institutions like the Cyber Teacher Training Center (CTTC) are taking advantage of the Internet to provide better ICT Diffusion in Nigeria's Higher Education.(JITI 2010). The government funded CTTC, established in 1997, offers self-directed, self-paced Web-based courses for primary and secondary school teachers. Courses include "Computers in the Information Society,"“Education Reform," and "Future Society and Education." Online tutorials are also offered, with some courses requiring occasional face-to-face meetings (Jung, 2002). In Nigeria, The National Open University of Nigeria, satellite-based video and audio conferencing was founded in 2000 by the former President, OlusegunObasanjo, supplemented by print-materials and recorded video, to train teachers who have not obtained the requisite degree for their current job placement from any geographical distance. The teachers interacted with remote lecturers by telephone and fax.

$>$ Access to remote learning resources: Teachers and learners no longer have to rely solely on printed books and other materials in physical media housed in libraries (and available in limited quantities) for their educational needs. With the Internet and the World Wide Web, a wealth of learning materials in almost every subject and in a variety of media can now be accessed from anywhere at any time of the day and by an unlimited number of youths. This is particularly significant for many institutions in developing countries, and even some in developed countries, that have limited and outdated library resources. ICTs also facilitate access to resource persons, mentors, experts, researchers, professionals, business leaders, and peers all over the world. Lecturers are able to break away from professional isolation. With ICTs, they can easily connect with lecturers from other countries and with sources of teaching materials. Therefore, with information more readily available, learners are not dependent on lecturers and librarians for information. Learners are helping redefine the role of lecturers and librarians so learners can focus on analyzing information and sharpening their critical thinking skills.

> ICTs have broken the barrier of distance in knowledge acquisition: With the advent of ICT and its subsequent diffusion in higher institutions in Nigeria, interactive electronic communication between two or more people from different geographical location is now used in teaching and exchange of ideas either inform of a conference, symposium, seminar or lecture. This technology known as video conferencing is already implemented in ObafemiAwolowo University (OAU) Ile-Ife as well as the National Open University of Nigeria (NOUN), which has various campuses situated across the country. This technology has become a driving force for educational reform, making it possible for teachers and learners (and related support professionals) to connect better to information, ideas and each other via effective combinations of pedagogy and old and new technologies. ICTs for teaching and learning undergo at least three phases:

$\checkmark$ a substitution phase where traditional teaching occurs with the use of new technologies;

$\checkmark \quad$ a transition phase where new teaching and learning practices begin to appear as established practices start to be questioned; and

$\checkmark$ atransformation phase where the new technologies enable new practices. Nigeria's tertiary institutions are now undergoing the transformative phase of this digital drive.

ICTs are altering the functions of libraries and changing the role of librarians: With a wealth of learning resources on the Internet, some of which are freely available, librarians are becoming information managers or cybrarians. These cybrarians will be computer experts and information brokers who will be involved in structuring and will be engaged in publishing as well as in teaching. To this end, researchers are no longer faced with a lack of information but a glut of information. Data sharing, peer review and developing a network of contacts are no longer constrained by distance as access to email, web based file and data sharing and web logs become more ubiquitous.

\section{$>$ There is an increasing prominence for ICT inclined institutions}


ObafemiAwolowo University (OAU) Ile-Ife was recently branded Nigeria's foremost ICT University because in 1998, it became the first university to establish an independent satellite link to the Internet (Idowu, et al. 2004). Presently, it is only OAU that has fully installed Internet facilities available to both staff and student mainly for academic or research purposes within the confines of the large campus. This has earned a lot of integrity and prominence for the university as far as Nigeria is concerned. Furthermore, universities are entering into partnerships with the private sector (for example, Lead City University, Ibadan) in order to stay current as well as to get help on maintaining operation and financial viability of ICT based education programs.

$\checkmark$ ICT Diffusion has lead to the efficient Institution of Distance Learning: University of Ibadan, ObafemiAwolowo University and the National Open University of Nigeria now operate distance learning centers, where a combination of print, live and recorded broadcast as well as the Internet is used to deliver courses or lectures to students. At the ObafemiAwolowo University, course materials are still predominantly print-based but online tutorials are becoming a convenient alternative to face-to-face tutorials specifically for students unwilling or unable to go to OAU's various physical learning centers. The Internet, and associated ICTs, is making it possible for various forms of cross border education, including trade in education. The relevance of traditional quality assurance mechanisms is being questioned and new mechanisms for ensuring quality in transnational education are being proposed.

There are still some factors that are pending the full utilization of ICT in Nigeria, especially in the Nigerian Tertiary Institutions where most of the youths can be located, in re-Branding of the Nigeria youths.

Some of these factors are as follows:

$\checkmark$ Inadequate Infrastructure,

$\checkmark$ Inadequate Skilled Manpower,

$\checkmark$ Resistance to Change

$\checkmark$ Inadequate Funding.

$\checkmark \quad$ Inadequate Infrastructure:Tertiary institutions in Nigeria lack adequate ICT infrastructure to effectively tap into the opportunities offered by the cyberspace. Personal Computers (PCs) are available in most Nigerian tertiary institutions, but they are not readily accessible to students because of the low computer (PC): student ratio which is averagely put at about 1 to 40 . In most cases, the basic software needed for practical works are not available and where they are available, they are not accessible because of the low ratio. There is also the lack of Computer Aided Interaction and some other specialized software to support some areas of teaching learning and research. Internet connectivity is available in most tertiary institutions in Nigeria, but in most cases the bandwidth subscribed to (which determine speed of access) is too small to support any meaningful academic (Achimuguet al.2010) activity during peak period. Some institutions have subscribed to Virtual Library sites whereby members can access electronic academic materials such as journals. Also some institutions have CD-Rom collections on specialized fields, but the currency of the information on the CDs cannot be guaranteed as no effort is made to update them Whereas ICT infrastructures like multimedia projectors are available in Nigerian tertiary institutions to support teaching, learning and research, other infrastructures like Interactive White Boards and mobile devices are lacking.

$\checkmark \quad$ Inadequate Skilled Manpower:Inadequate ICT technical personnel are a major problem in Nigerian tertiary institutions. The reason for this can be ascribed to the lucrative job opportunities available to ICT professionals outside the academics. The situation has made institutions rely on commercial private ventures to provide support for the few ICT facilities available. The support offered is in most cases are commercial and lack academic content. As a way out of this challenge, some universities like ObafemiAwolowo University IleIfe, Lead City University Ibadan, Bowen University Iwo and National Open University of Nigeria are in partnership with private and international organizations for ICT technical manpower development.

$\checkmark$ Resistance to Change:There is the concern of faculty members not willing to take the "soft" approach to teaching and learning. Rather, they stick to the traditional hard "approach". Report from OECD (2005) gave reasons while faculties resist e-learning for example. These include:

That e-learning development, with its standardization aspects, might conflict to some extent with the professional culture of academic, based on autonomy and reward system often based on research.

Concern about intellectual property rights and shared rights between faculty, institutions and technologies. 
$\checkmark$ Inadequate Funding:This is the major challenge confronting the acquisition and utilization of ICT in Nigerian tertiary education. Most institutions solely rely on their proprietor for funding and the bulk of such fund goes to servicing the overhead cost. Since no clear sustainable business model has yet emerged for commercial provision of e-learning, and failures have been more numerous than success, (OECD, 2005), institutions are not willing to invest the little fund available to them on e-learning project.

\subsubsection{TELECONFERENCING AND TELECOLLABORATION}

Teleconferencing and telecollaboration have both facilitated the exchange of all forms of data between youths at different locations.Teleconferencing, through networks has ensured the passage of information from teacher to learner and learner to learner. It's also been found to be used in non formal settings such as peer groups where youths working in a group can share and exchange information. Teleconferencing and telecollaboration have both ensured the breaking down of ethnic, tribal and social barriers among youths. Youths from different backgrounds, ethnicity, and social class are able to together and share information that could help them become bright and better citizens as well as excellent students in their various fields of academic endeavor. They have also helped to unite Nigerian youths thereby making it easy and possible to achieve remarkable results in manpower development of Nigerian youths.

\subsubsection{Collaborative Workspaces}

The relative merits of Email and Collaborative Workspaces have been cogently summarized by Michael Sampson (2004) as follows: "Email. Strengths are universal addressability, universal interoperability, and cross-organization functionality, offset by weaknesses of disconnection between its design and current usage pattern, a deluge of spam, and a lack of immediacy, among others." Collaborative Workspaces strengths are the provision of a set of structured tools for group work, enforced group memory, and shared content taxonomy, with weaknesses of poor cross-platform support, lack of cross-product interoperability, and poor cross-enterprise capabilities."

\subsection{THE IMPACT OF ICT ON GOVERNMENT IN REBRANDING NIGERIAN YOUTHS}

Dr. Myles Munroe, a motivational speaker and author of the Spirit of Leadership, tries to capture the essence of leadership and qualities for which it can be successful. According to him, "A genuine leader does not seek power but is driven by a passion to achieve a noble cause ... What distinguishes a true leader is having the rare qualities, which are: passion, vision, discipline, determination, drive, self-sacrifice and courage." The government is an institution that cannot operate without the advances provided by Information and Communication Technology (ICT). Information technology probably has more impacts on governments than corporations and private individuals. Some areas where corporations propel and advance technology, Consumers (the youths) then jump on the bandwagon embracing new and wonderful gizmos and ideas. Governments, on the other hand, usually lag behind and are forced to catch up. And even if they do not want to be involved, they must, because current trends and business practices demand that they conform. But this leaves governments vulnerable in many ways and thus, it can be said that generally speaking, information technology has a negative impact on governments. But the positive impacts are to be considered in this work. In Nigeria, the ICTs have also helped to impact on the livelihood strategies of small-scale enterprises and local entrepreneurs as well as in the enhancement of various forms of social capital. A proportion of the research literature discusses social capital and ICT from general internet studies as well as specifically place based research (O'Neil 2002).The first issue, here is that governments are not leaders in technology. They react to the environment around them rather than trying to find new ways of efficiency. As a result, it is more costly to change everything over at once dispensing large sums of cash to meet equipment needs and staff training requirements. It also leads to more inefficiency as new systems are confused with old and chaotic situations occur.Secondly, governments hold confidential information derived fromboth the data from its individual citizens and country specific security data. As all information becomes digital and available to anyone who cares to see it, security breaches are inevitable. And while many corporations have had scandals regarding customer information being leaked or hacked, governments are more susceptible, as they rarely attract the best IT people in the field as employees. Developments in information technology have helped governments to improve their services to their citizens. Advances in Database technology for example have enabled the governments of various countries to collate and monitor statistical information that they can use to combat fraud, manage the economy in a better way. The advances in information technology have heavily influenced commercial businesses in several ways. The most important role of information technology in a commercial business is to provide a commercial advantage. Advances such as computer aided design; relational database technologies, spreadsheets and word processing software all provide a commercial benefit to the business, as automation of manufacturing processes and as different businesses compete with each other, the commercial advantage one can have over another may depend primarily on its use of information technologies. For example being able to extract information as to what the 
customer really wants and how to provide for that want can provide a significant advantage. This extraction of information is facilitated and indeed made possible by the technology used to store and manipulate this information. As the hardware and software mechanisms used to store and manipulate the information become more sophisticated and quicker the business can utilize its stored information to maximize its commercial advantage. The use of information technology to monitor a business's performance can also enable the business to highlight areas where they are not making the most use of their resources. The use of information technologies can also increase the businesses income through advertising in the various available forums. Due to the nature of news and media organizations, the information technologies have particular relevance to them.Recently in Abuja, the Telemedicine and E-Health Project within the eGovernment initiative was discussed at the eGoverment conference. The Nigeria healthcare delivery system is attempting to cross the digital divide with the deployment of ICT to meet the millennium development goals in the sector. Telemedicine and eHealth are critical factor for health care delivery at all levels which bears direct impact on meeting the millennium development goals. ICT in health care changes the paradigm of health care delivery to one that is patient- centered, allowing the patient to gather health related information themselves and communicate with care providers. ICT is being adopted by many governmental organisations sectors such as NAFDAC and NDLEA. The drug control sector is benefiting from multi-lateral co-operation using information technology. The international law enforcement family has been adopting the use of IT. (Oluwafummike, 2002)

\subsection{THE IMPACT OF ICT ON RELIGION IN REBRANDING NIGERIAN YOUTHS}

Religion is the opium of the people as defined by Karl Max, but this statement may not hold again as more information is available to judge it.

Looking at the impact the digital revolution has had on traditional churches and denominations. The "digital turn" raises many questions concerning religious faith and practices of today. For example: What does it mean for traditional religious structures and ritual practices that faith moves from physical buildings and the physical congregation to cyberspace? What happens with traditional clerical hierarchies in cyberspace? How does religion online differ (if so) from religion off line? Is it possible to keep faith in an absolute truth when the pluralistic nature of the Net tends to promote pluralism and relativism (the flipside is an increasing fundamentalism) that if people live their religious life on Internet, and if churches and various religious representatives are online, theologians have to go online at the same time. The mobile bible has made the word of God available for everybody to read and have references on at any time. The satellite channels also have fuel the availability of the word of God to the rooms of the youths thereby creating the avenue for spiritual uplift.The internet is not left out here as any religious material can be accessed on any scriptural content.

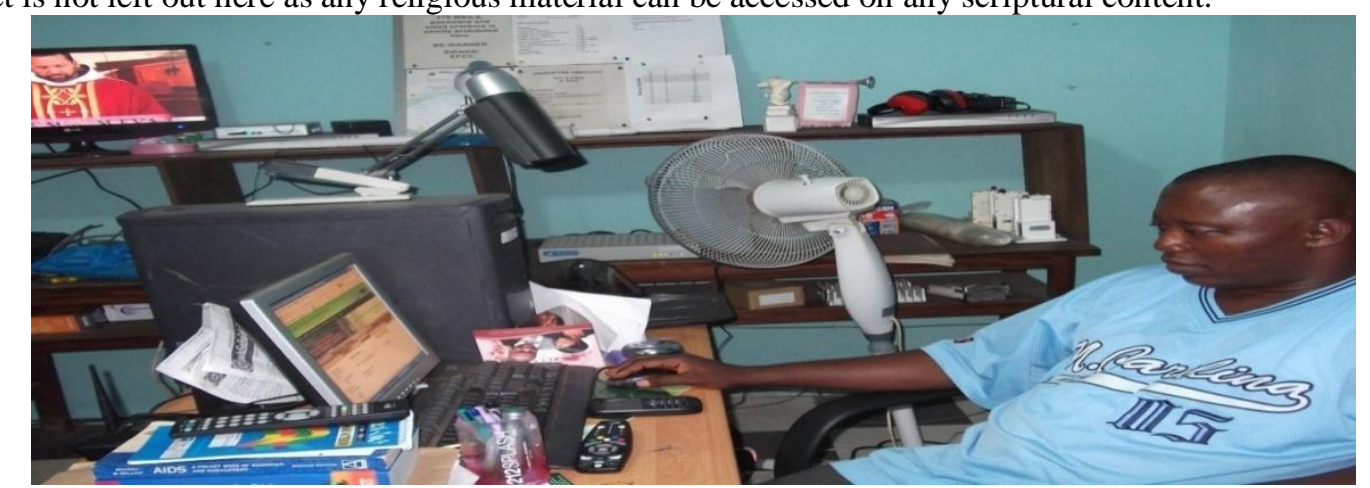

FIG. 3- A PASTOR ACCESSING RELIGIOUS MATERIAL THROUGH THE INTERNET

\section{Change in behavioural and attitudinal pattern}

Due to the availability of ICT infrastructure, religious groups have been able to reach out to many people especially the youths with teachings encouraging them to abstain from immorality, be at peace with their neighbours and to live a life that is honourable. With this trend, some youths that would have indulged in some crimes refrain from them on hearing/reading messages on the internet, on their mobile phones, cable TV, and other forms of message broadcasting. In the long run the religious groups would have succeeded in accomplishing part of their aims which is getting people to have the knowledge and understanding about the God they are worshipping and professing. Some churches now make use of plasma television and Internet facilities to participate or conducting their both International and local fellowships and studies as shown below: 


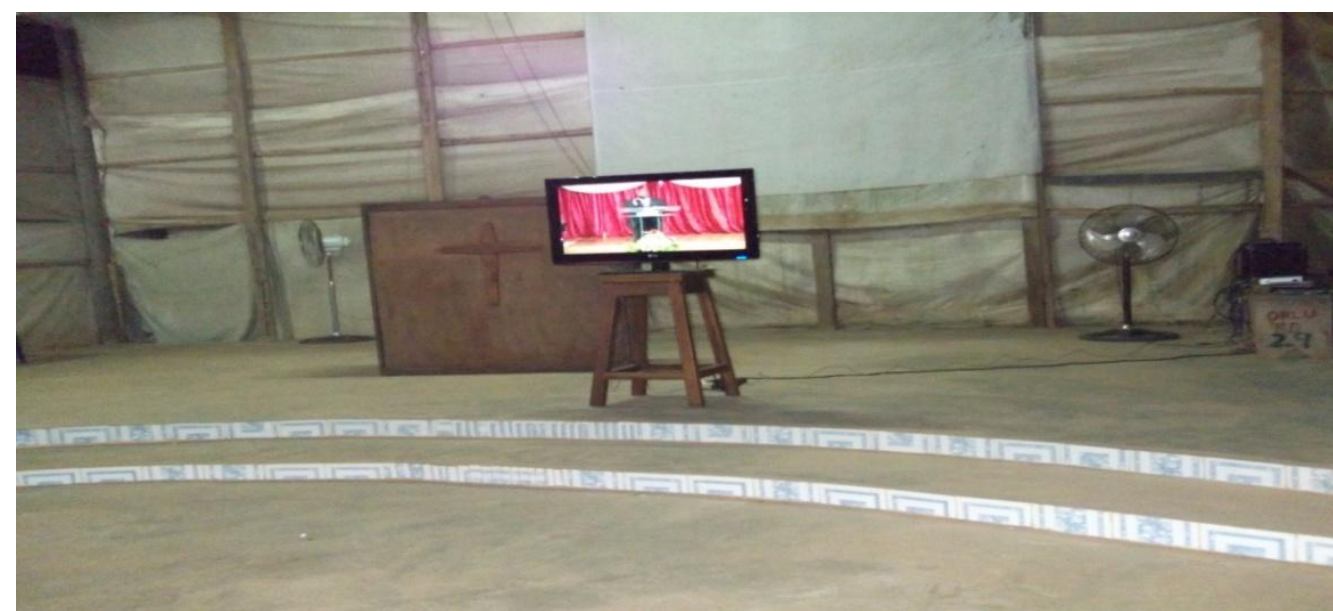

FIG. 4 - USING PLASMA TELEVISION WITH THE HELP OF INTERNET FOR PREACHING IN THE $\mathrm{CHURCH}$

\section{$\checkmark \quad$ Increase in the number of followership}

Before the dawn of ICT in Nigeria, religious groups were finding it more difficult than now in preaching their messages and converting souls on a large scale. This situation took a different dimension when ICT was introduced; these religious groups now find it easy to overcome barriers in distance, culture, language and the like as there are means of reaching out to almost everybody on the globe at the same time. With this feat, more members are added daily to the different folds.

$>$ ICT religion can positively impact in the following ways:

$\checkmark$ Creating online discussion groups, blogs, and web casts to ensure an integration/reintegration of religion activities into Nigeria societies, aswell as to facilitate participation in the decision-making process for various religion denomination in Nigeria

$\checkmark$ Using the Internet as a transnational sphere where Nigeria youths can produceand debate narratives of religion history and identity.

$\checkmark$ Producing ethnic (Internet) radio and/or television programs which the Nigeria youths can part take in.

$\checkmark$ Encouraging religious research partnerships. Example, use the Internet as a meeting space, linking religious group.

$\checkmark$ addressing the need for job creation and the provision of job opportunitiesthrough telework and/or business outsourcing opportunities

$\checkmark$ Establishing telecommunication centers as an important physical meeting place wherechurch groups can gather and make connections with other international churches.

\subsection{THE IMPACT OF ICT ON ECONOMY IN REBRANDING NIGERIAN YOUTHS}

The impact of ICT has been felt on the Economic Development of our nation Nigeria. The rebranding of Nigeria youths through the advances in ICT can be narrowed down to but not limited to the following points:

\section{$\checkmark$ Reduced transaction costs}

The cost of purchasing of goods or the acquisition of services has drastically reduced. The internet has remained the source or the eye to the outside world. E-commerce- the buying and selling of goods and services over the information super-high way has made a lot easy for effective online business. The possibility of meeting foreign businesses has brought competition between the locally own ones and foreign ones, and has contributed to the reduction of the prices of goods as the society or the youths can buy from a variety of online stores. It has also encouraged our locally made product since the foreign market can access our product online and place orders on them without us exporting them there. This brings revenue for us and increases our bilateral relationships with other countries especially when the products are national products like oil. Similarly, ebanking has offered great assistance in business transactions through ATM 


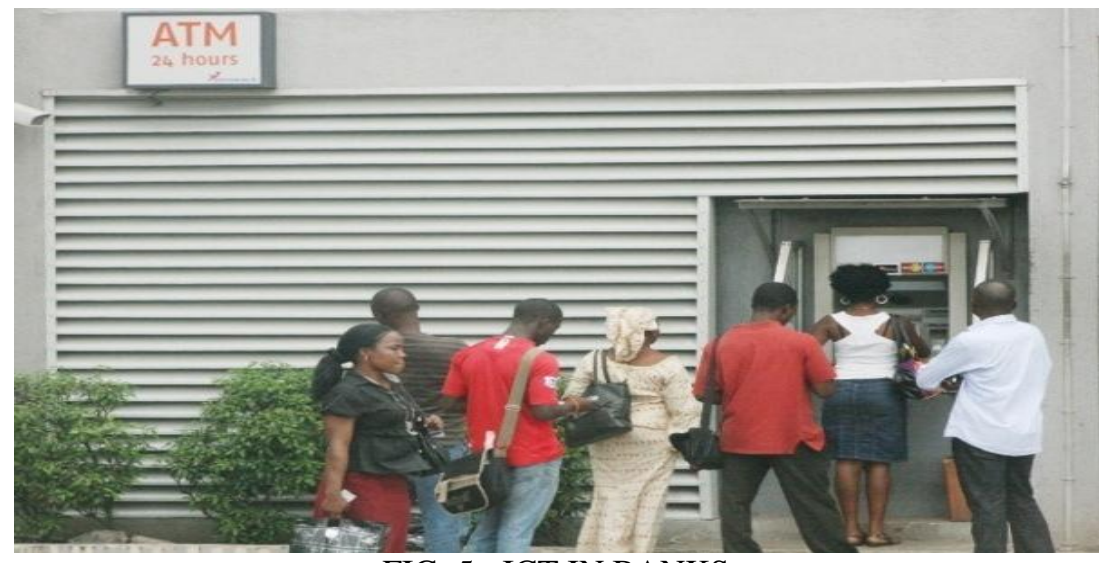

FIG. 5 - ICT IN BANKS

\section{$\checkmark$ Increased productivity}

The procurement of raw materials today for production is being influenced by Information and Communication Technology, in that the right information is obtained online and the purchase can be made, and the technical-know-how personnel needed for production can be employed by the placement of advertisement on the media for application and from here the best qualified can be employed.

$\checkmark$ New trade opportunities

$\checkmark$ Access to knowledge (important to firms)

$\checkmark$ Increased competition

$\checkmark$ Better communication

\subsubsection{POVERTY AND UNEMPLOYMENT RATE}

There have been conflicting opinions about the current unemployment rate in the country while the official publication of Federal Government during the Obasanjo era said unemployment rate was reduced to $50 \%$. However, the recently published census figure (2007) and that of NDE put the unemployment rate at $70 \%$. The most reliable document today is the official statistics from the World Bank.

\section{Source: CIA World fact book (Nigerian Unemployment Rate) April 2007} http://www. index mundi. com/nigeria/unemployment.

In 1984 the unemployment rate nationally was $6.4 \%$ while in 2007 it stood at $5.8 \%$. At the state level, unemployment for urban was $2.90 \%$ and $1.40 \%$ for rural respectively. It indicated that there has been reduction in the unemployment rate when compared with the data obtained in 1984.

The reduction may be connected to the various capacity developmental measures taking by the government.

\subsubsection{VARIOUS EFFORTS ON REDUCING UNEMPLOYMENT AND POVERTY RATES}

There are several, efforts at reducing the high rates of unemployment and poverty. Some of these are NEEDS and SEEDS

\section{What is NEEDS?}

According to the National Planning Commission (2004), it is a strategic plan by the Federal Government to generate employment, reduce poverty and inculcate value orientation and discipline in the people. To achieve the above, the process involves the establishment of macroeconomic environment that will empower people, promote private enterprise and change the way government does its work.

\section{What is SEEDS?}

The State also established State Economic Empowerment and Development Strategies

(SEEDS). It is to encourage the establishment of small scale or medium size businesses. The Directorate of Employment, Commercial Banks and other Non Governmental Organizations (NGOS) rose to the challenge. A lot of employments have been created through the intervention of Commercial Banks like Oceanic, U. B. A. and Telecommunication Industries like Glomobile, MTN, Celtel, O-Net, M-Tel and Multi-link. The commercial banks provided the necessary knowledge and skill acquisition for youths in ICT after completion of the training, they were provided with loan to start small scale computer and internet services. 
While the Telecommunication Industries provided facilities for small scale Telephone Centers in both the rural and urban centers. These groups of youth were closely monitored. Apart the above, there were healthy competitions among the different network providers. In order to win more customers the money to purchase handsets and lines were generally reduced. Preference was given to youth wanting to start small scale telephone business. Many of the youths took up the opportunity offered.Kirkman, Schwab and Cornelius (2002) say, ICT is yet to be adopted or widely used by the youths, but it is those people who are yet to use the internet on a telephone that will gain the potential of ICT. As a result of the potential of ICT in meeting the challenges of youth unemployment, it was adopted both at the national and the state level. The picture below shows small scale Telephone repair center

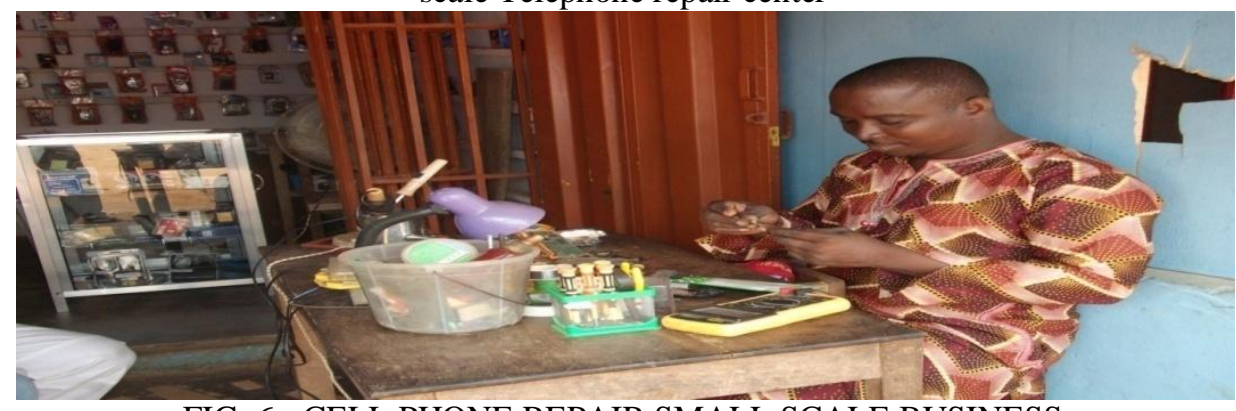

FIG. 6 - CELL PHONE REPAIR SMALL SCALE BUSINESS

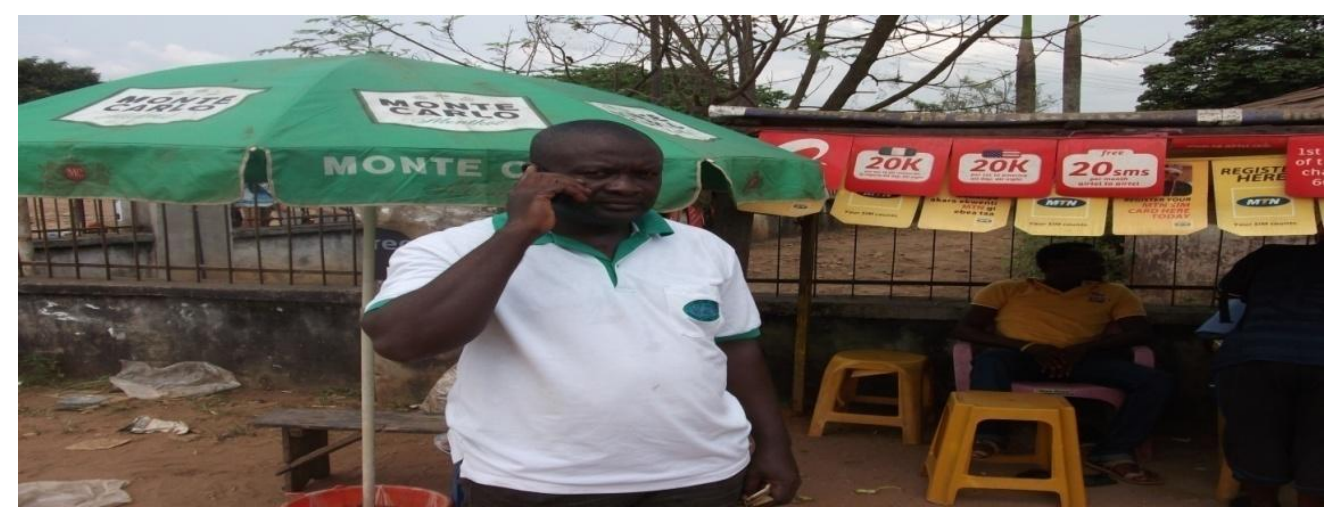

FIG. 7 - CELL PHONE CALLS SMALL SCALE BUSINESS

\subsubsection{ICT AND EMPLOYMENT GENERATION}

There is accelerated development through ICT. Philip (2002) quoting the South African Communication Minister says, "The knowledge revolution is upon us, we cannot wish it away". The question is how we respond to it. The Minister therefore called on the delegates to find imaginative ways by which the labour force can be educated to take up the advantages of job opportunities available through ICT. Today there is shift from low-skilled to high skilled labour force. She also calls for a comprehensive campaign to encourage more youths to acquire necessary skill in ICT. In Nigeria the youth have yielded to the call and are using ICT as a launching pad to create entrepreneurial activities such as mobile telephoning, internet cyber café and computer services. In Osun State for example, there are 200 cyber cafés with a minimum of 10 computers. This is in addition to the mobile community telephone centers in both the rural and urban centres. Cyber cafe facilities are situated only in the major cities where there are higher institutions of learning. This effort is being gradually integrated to the rural communities though at a slow speed as a result of some challenges that include power supply, lack of necessary infrastructures and negative attitudes.

Several foundations like: Fantsaum, Copine in ObafemiAwolowo University, Ile-Ife has facilitated access to ICT in the rural communities. Fantsaum foundation has also provided their members in the rural communities with accesses to micro credits and ICT services for educational and economic empowerment and health. In addition they provided ICT skills training and technical support. Studies indicate that for every US\$1 invested in telecommunications infrastructure, more than US\$6 is generated in economic returns by its impact on local employment and general economic growth. GSM service had opened many job opportunities for the jobless people. The profits of phone business centers have great impact wellbeing of the household. Cyber cafes as well, are creating great opportunities for young people to be employed and at the same time exploit the advantages of internet. 

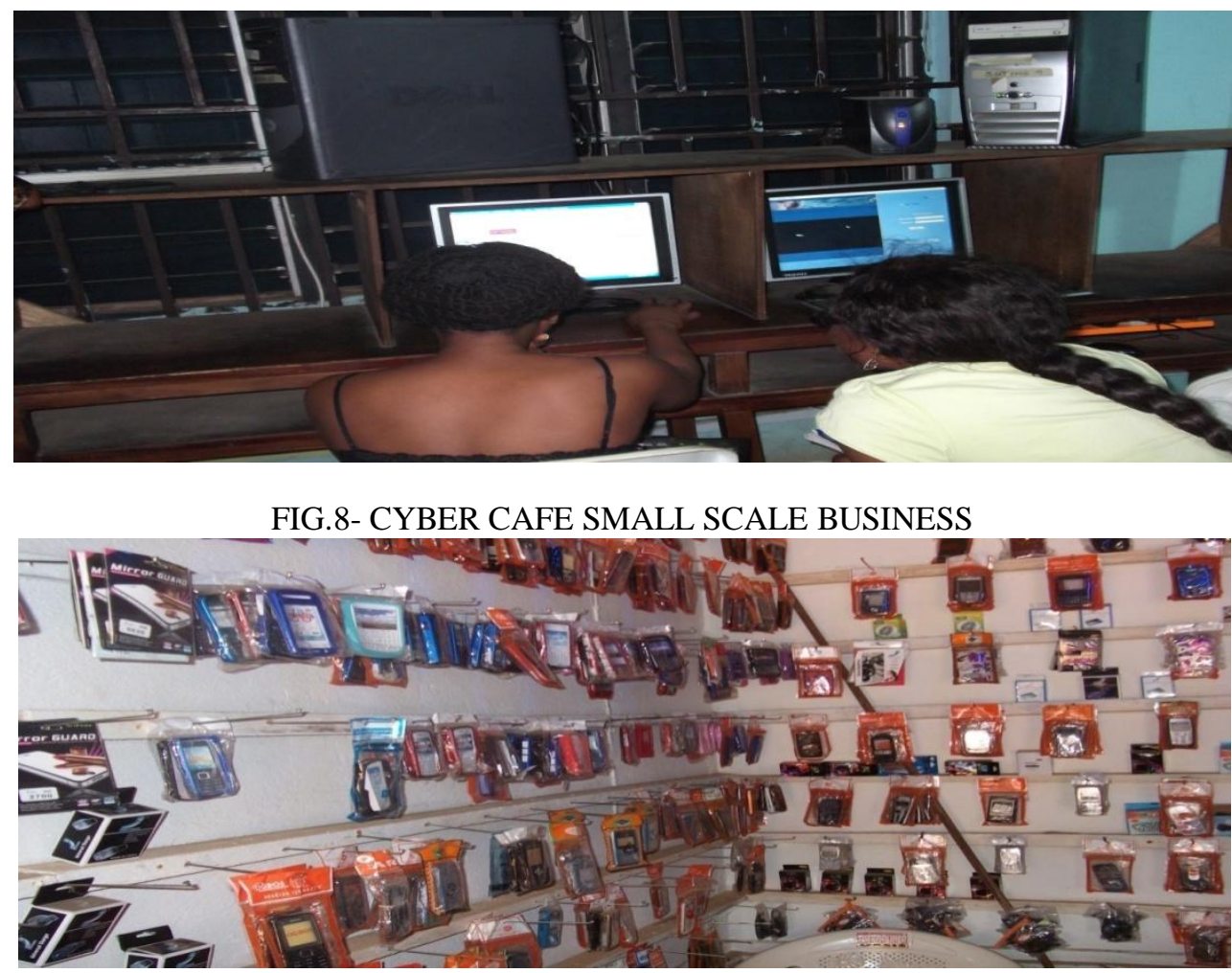

FIG.9- CELL PHONE ACCESSORIES SMALL SCALE BUSINESS

\section{Areas of Major Influence}

$\checkmark$ Automotive industry (Internet-related productivity gains from significant improvement in supply chain management)

$\checkmark \quad$ Financial services (Productivity gains from transparency, pricing and disintermediation)

$\checkmark \quad$ E-government initiatives (Increased transparency and better prices)

$\checkmark$ Airline industry (Productivity gains from transparency, pricing and disintermediation)

3.1 ICT IMPACT ON ECONOMIC GROWTH

$\checkmark$ Increased labour productivity

$\checkmark$ More rapid multifactor productivity growth in ICT producing sector.

$\checkmark$ Users of ICT increase overall efficiency

$\checkmark \quad$ Network effects

\subsection{ICTIMPACT AT THE FIRM LEVEL}

$\checkmark$ Positive impact of ICT but conditional on other factors: skills, innovation, organizational change, experimentation

$\checkmark$ Can improve productivity \& help efficient firms gain market share

$\checkmark$ Impacts of ICT also found in the services sector

$\checkmark$ Impact on labour-skill biased technological change.

\subsection{ECONOMIC EVALUATION OF ICT IN NIGERIA}

$\checkmark$ The use of ICT raised aggregate multi-factor productivity about $0.2 \%$ points

$\checkmark$ Impacts are largest in finance and insurance

$\checkmark$ Impact tapers off overtime - they are largest a few years after adoption

$\checkmark$ Complementary factors play a large role in explaining firm's success with ICT

$\checkmark$ Early users of ICT are large firms with skilled managers

$\checkmark$ Firms with high openness to trade use more ICT

\subsection{ICT USAGE BY SMALL AND MEDIUN SCALE ENTERPRISES IN DEVELOPING NIGERIA \\ $\checkmark$ Many firms connected to Internet, particularly in urban areas. \\ $\checkmark$ But Internet is not fully exploited \\ $\checkmark$ Readiness to invest constrained by: \\ - perceived limited impact on profitability}


- $\quad$ limited number of suppliers\& customers online

(Source: E-Commerce \& Development Report 2004)

\subsection{DIFFERENCES IN ECONOMICS ANALYSIS}

$>$ Direct Costs of ICT

$>$ Cost and implementation barriers to enabling factors

- Lack of skills

- Adjustment costs

- Different levels of innovation

- Risk and uncertainty(Policies to enhance labour use may reduce capital labour substitution)

- Nature of business

- Competition not equally strong

\subsection{ICT Enhances Economic Effectiveness, Efficiency and Reach of Technical Assistance}

Information communication technologies (ICTs) can provide farmers, entrepreneurs and others in emerging economies with market information vital to their work and success. A lack of timely and accurate information is a significant barrier to competitiveness for micro, small and medium-sized enterprises (MSMEs), which are now widely recognized as the prime engine of growth in most of the developing world. To address this gap, we use ICT and other multimedia technologies to stimulate and meet increased local demand for market information. We also use ICTs to provide farmers and other beneficiaries with much-needed credit information and technical knowledge, assistance and services.

\section{Conclusion \& Recommendations}

As already elucidated in this text, Information and Communications technology (ICT) has greatly rebranded the Nigerian youth in many respects such as education, government, religion, economy, environmental sustainability, security, etcInformation and communication technologies have become a significant factor in development, having a profound impact on the political, economic and social sectors of many countries. While many equate information and communication technologies primarily with mobile and more advanced technologies, a more useful definition of information and communication technologies include all technologies that enable the handling of information and facilitate different forms of communication. By expanding the notion of information and communication technologies to include both older and newer technologies, from newspapers, radio and television to camcorders, cell phones, computers and network hardware and software, satellite systems and so on, as well as the various services and applications associated with them, such as videoconferencing and distance learning, the full impact of ICT on the social development of youth can be better understood. ICT are often spoken of in a particular context, such as ICT in education, health care, or libraries, the distinction between old and new technologies may become outdated as radio, television, satellite technologies and the Internet are combined in innovative ways to reach a wide range of target audiences.

The development of ICT has its pros and cons. Some of the side effects include the use of computers to replace human labor, internet scam, erosion of Nigeria cultural values as a result of exposure to modern foreign media etc. On the other hand ICT has helped in the improvement of communication, trade, politics, health, education, socio economic development etc.Many Nigerian youths do not make effective use of ICT, which leads to their underdevelopment and that of the nation. $80 \%$ of youths in Nigeria tend to misuse ICT particularly the internet, to search for extraneous information such as hip hop stars and music, chatting with unknown people from other parts of the world, viewing of immoral sites and materials and most especially internet scam (419), while $15 \%$ use it for job search, mailing and contact point. The other $5 \%$ are those that make effective use of ICT. They access information on health, education, politics, and socio economic development, research for project, use it to develop their life building and skills, carryout legal businesses etc.

\section{Recommendations}

$>$ Government should promulgate laws and policies to guide the use of ICT

$>$ Professional bodies such as NCS (Nigerian Computer Society), CPN(Computer Professionals of Nigeria) etc. should monitor the establishment and management of ICT centers in the country.

$>$ stakeholders (including the government, schools, private sector, individuals (youths), non-governmental organizations, etc) to fully exploit the opportunities made available by ICT for the development of youths and the nation at large.

$>$ Government should ensure proper implementation of the policies and equally integrate these policies and their implementation into the budget and overall strategic plans.

$>$ Government should also review the educational curriculum of its schools to accommodate and be responsive to the changing landscape of industry demands. 
$>$ Government should reduce its dependence on oil and diversify investments into ICT for sustainable economic growth and development of the nation as done in other countries like India, Japan, etc.

$>$ Measures to improve access to the Internet and to increase information technology literacy at large should be encouraged.

$>$ Individuals especially youths on their part, should be personally committed to ICT education and making effective use of ICT for personal and national development.

$>$ Youths should be willing to put in the necessary efforts and required resources at their disposal knowing very well that ICT is a responsibility for all and should not be left to government alone.

\section{Conclusion}

All over the world, the use of Information and communication Technology is changing the face of teaching, learning, research, economy, religion and government. Information is a key factor to any development process. The Internet as an information and communication medium has come to play a major role in the distribution of information.Lack of access to information and communication technologies has remained a major challenge to youth development. The youths are only key players in the information society if they have been well educated, which gives them with the informational abilities to survive in a new and globalized economy.

Over the years, when it comes to international media and internet, Nigeria has been associated with bad images. Doing business or any form of online activity has always posed a challenge. For effective re-branding all components of ICT and at all levels must be deployed in enlightening, training, and encouraging people towards re-branding to enable them redeem their image. Special efforts must be made for youths especially those in rural areas to establish connectivity. Glad enough, rapid developments in wireless technology have made it possible to overcome the physical impediments of distance and topography, at a reasonable cost, This has been a barrier to the development of telecommunications infrastructure in rural areas. Shared access to these services can increase their impact. In most remote and sparsely populated areas, existing market incentives may often provide insufficient stimulus to private investment and government funding may be required.Nongovernmental organizations, the private sector, and well meaning individuals also should take it upon themselves to provide internet access to youth, ICT education and making effective use of ICT for personal and national development.

\section{Referenecs}

[1]. African Development Forum (1999).The process of developing national information andcommunications infrastructure (NICI) in Africa. Retrieved from http://www.uneca.org/adf99/nici.htm

[2]. Cloke, C., \& Sharif, S. (2001). Why use information and communication technology in schools? Some theoretical and practical issues.Journal of Information Technology for Teacher

[3]. Education, 10(1 \& 2), 7-18. Retrieved from http://www.triangle.co.uk/jit/index.htm

[4]. Culp, K. M., Honey, M., \&Mandinach, E. (2003). A Retrospective in Twenty Years of

[5]. Educational Technology Policy. Retrieved from http://www.nationaledtechplan.org//20years.pdf

[6]. Davis, N. (2003). Technology in teacher education in USA: What makes for sustainable good

[7]. practice? Technology, Pedagogy, and Education, 12(1), 59-84. Retrieved from http://www.triangle.co.uk/jit/index.htm

[8]. Federal Republic of Nigeria (2001).Nigeria National Policy for Information Technology (IT).

[9]. Retrieved from http://www.nitda.gov/docs/policy/ngitpolicy.pdf

[10]. Hafkin, N. (2002). Gender issues in ICT policy in developing countries. An overview. United

[11]. Nation's Division for the Advancement of Women (DAW) Expert Group meeting on

[12]. Information and Communication Technology and their impact on and use as an instrumentfor the Advancement of Women, Seoul, Republic of Korea. Retrieved from

[13]. http://www.apc.org/english/capacity/policy/mmtk_gender_ictpol_hafkin.pdf

[14]. Idowu, P. A., Abimbola, O. I. \&Adagunodo, E. R. (2004). A Comparative Study Of

[15]. Information and Communication Technologies at Higher Educational Institutions in Africa:Case Studies from Nigeria \& Mozambique. Journal of Information Technology Impact,4(2), 67-74.

[16]. Jung, I. (2002). Issues and Challenges of Providing Online In-services Teacher Training:

[17]. Korea's Experience.Retrieved from http://www.irrodl.org/content/v2.1/jung.pdf

[18]. Pearson, J. (2003). Information and communication technologies and teacher education in

[19]. Australia. Technology.Pedagogy and Education, 12(1), 39-58. Retrieved from

[20]. http://www.triangle.co.uk/jit/

[21]. Selinger, M., \& Austin, R. (2003). A comparison of the influence government policy in

[22]. information and communications technology for teacher training in England and NorthernIreland. Technology, Pedagogy and Education, 12(1), 19-38. Retrieved from

[23]. http://www.triangle.co.uk/jit/

[24]. Wadi, D., \& Sonia, J.(2002). ICT for Education: Potential and Potency. InW.Haddad\&A.

[25]. Drexler (Eds.), Technologies for Education: Potentials, Parameters, and Prospects

[26]. (Washington DC: Academy for Educational Development and Paris:UNESCO), pp.34-37 Watson, G. (2001). Professional development that engage with teachers' hearts and mind.

[27]. Information Technology for Teacher Education, 10(1\&2), 17-19. Retrieved from

[28]. http://www.triangle.co.uk/jit/

[29]. Yusuf, M. O. (1998). An Investigation into teachers' competence in implementing computer

[30]. education in Nigeria secondary schools. Journal of Science Teaching and Learning,3,(1\& 
[31]. 2), 54-63

[32]. OECD.(2005). E-Learning in Tertiary Education. Policy Brief by the Organization for

[33]. Economic Co-Operation and Development.

[34]. Achimugu et al.2010 Lecturer at the Department of Computer Science of Lead City University, Ibadan, Nigeria, Block A, Room 109, Faculty of InformationTechnology and Applied Sciences. Phone: +23480 5289 1485; Email: check4philo@ yahoo.com

[35]. Nigerian Communications Commission (2001) Telecommunication in Nigeria-Overview

[36]. http://cbdd.wsu.edu/kewlcontent/cdoutput/TR501/page9.htm

[37]. http://tutor2u.net/business/ict/intro_what_is_ict.htm 